\title{
Evaluation of customized dry-period strategies in dairy cows
}

\author{
A. Kok, ${ }^{1,2} \odot$ R. J. van Hoeij, ${ }^{2} \odot$ B. Kemp, ${ }^{2} \odot$ and A. T. M. van Knegsel ${ }^{2 *} \odot$ \\ ${ }^{1}$ Animal Production Systems group, Wageningen University, P.O. Box 338, 6700 AH Wageningen, the Netherlands \\ ${ }^{2}$ Adaptation Physiology group, Wageningen University, P.O. Box 338, 6700 AH Wageningen, the Netherlands
}

\begin{abstract}
Shortening or omitting the dry period to improve the energy balance in early lactation have the trade-offs of reduction in milk production and loss of opportunity for dry-cow therapy (DCT; i.e., intramammary antibiotic use at dry-off). Customized dry-period strategies (i.e., deciding upon DCT and dry-period length per cow) could mitigate negative effects of short or no dry periods on milk production and udder health and simultaneously retain benefits from improved energy balance and fertility. In this study, we evaluated 3 decision trees to customize dry-period strategies for individual cows. In the control tree $(\mathrm{CT})$, all cows had a 60-d dry period, with DCT if somatic cell count (SCC) was $>150,000$ cells $/ \mathrm{mL}$ before dry-off. In decision tree 1 (T1), parity 1 and parity $>1$ cows were assigned DCT if SCC was $\geq 150,000$ cells $/ \mathrm{mL}$ and $\mathrm{SCC} \geq 50,000$ cells/ $\mathrm{mL}$, respectively; whereas in decision tree 2 (T2), the threshold for DCT was SCC $\geq 200,000$ cells $/ \mathrm{mL}$ for all animals. In $\mathrm{T} 1$ and $\mathrm{T} 2$, cows with $\mathrm{DCT}$ were assigned a 60-d dry period, whereas cows without DCT were assigned a $30-\mathrm{d}$ or $0-\mathrm{d}$ dry period if their milk production remained $>12 \mathrm{~kg} / \mathrm{d}$ at 67 and $37 \mathrm{~d}$ before calving, respectively. Cows were monitored from 8 wk before to 14 wk after calving. Milk production and composition, SCC, body condition score, body weight, and occurrence of treatment for disease (related to calving and start of lactation) were compared between CT ( $\mathrm{n}=$ 61 cows), $\mathrm{T} 1$ ( $\mathrm{n}=59$ cows), and $\mathrm{T} 2$ ( $\mathrm{n}=63$ cows). Effects of decision trees (CT, T1, T2) and of dry-period strategies (60-d dry with or without antibiotics, 30-d dry, or 0 -d dry) on measured variables were analyzed separately with mixed models, effects on udder-health status with a logistic regression, and occurrence of treatment for diseases with a Pearson chi-squared test. In $\mathrm{T} 1,36 \%$ of cows qualified for $30-\mathrm{d}$ and $2 \%$ for $0-\mathrm{d}$
\end{abstract}

Received April 15, 2020.

Accepted August 22, 2020.

*Corresponding author: ariette.vanknegsel@wur.nl dry periods, whereas in T2 this was $51 \%$ and $30 \%$ for 30-d and 0-d dry periods, respectively. Compared with $\mathrm{CT}$, cows in T1 and T2 on average produced more milk in the 8 wk before calving ( 0.2 vs. 3.9 vs. $7.1 \mathrm{~kg} / \mathrm{d}$ in CT vs. T1 vs. T2), and less in the 14 wk after calving (40.0 vs. 37.0 vs. $35.2 \mathrm{~kg} / \mathrm{d}$ in CT vs. T1 vs. T2). There was no difference in udder-health status in the transition period among decision trees. In the first $14 \mathrm{wk}$ after calving, recovery of body weight was greater for T2 than CT and T1. Overall, 30-d and 0-d dry periods reduced milk revenues, but this might be financially compensated by improved cow health with customized dry-period strategies.

Key words: dry-period length, dry-cow antibiotics, selective dry-cow therapy, continuous milking

\section{INTRODUCTION}

Dairy cows are generally managed for a dry period of 6 to $8 \mathrm{wk}$. This dry period facilitates the replacement of senescent mammary epithelial cells (Capuco et al., 1997), and thereby maximizes peak milk yield in the next lactation (Kuhn et al., 2005). In the first months of lactation, however, a high milk yield in combination with a limited feed intake results in a negative energy balance (de Vries and Veerkamp, 2000; Rastani et al., 2005). A severe negative energy balance is associated with reduced health and fertility (Ingvartsen, 2006; Esposito et al., 2014).

Shortening or omitting the dry period of dairy cows can improve the energy balance and metabolic status in the next lactation through reduced milk production and similar or increased feed intake in early lactation (Andersen et al., 2005; Rastani et al., 2005; de Feu et al., 2009). The improvement in energy balance in early lactation following a short or no dry period can be hypothesized to reduce the incidence of diseases and disorders associated with the negative energy balance in early lactation (Collard et al., 2000; Lucy, 2001), which indeed seemed to be the case in some studies (Rastani et al., 2005; Schlamberger et al., 2010; Köpf et al., 2014). However, experimental data to verify this hypothesis is limited in animal numbers (van Knegsel 
et al., 2013). The improvement in energy balance in early lactation following a short or no dry period was associated with improved fertility, including improved resumption of ovarian cyclicity postpartum (Gümen et al., 2005; Chen et al., 2015b) and, in some studies, fewer days open (e.g., days open of 94 d vs. 121 d vs. 145 d open for 0-d vs. 28-d vs. 56-d dry periods; Gümen et al., 2005). Moreover, the effect of dry-period length on milk production and energy balance depend on cow characteristics such as parity, production level, and udder-health status (Annen et al., 2004; van Hoeij et al., 2016; Kok et al., 2017a).

Despite its potential benefits for the cow, shortening and omitting the dry period have trade-offs. First, short and no dry periods resulted in milk production losses of $4.5 \%$ and $19 \%$, respectively, in the subsequent lactation (van Knegsel et al., 2013), which was estimated to translate into total yield reductions of $3.1 \%$ and $3.5 \%$, respectively, at the herd level (Kok et al., 2017b). Second, shortening, and especially omitting, the dry period interfered with the possibility to treat cows with subclinical mastitis with dry-cow antibiotics (van Hoeij et al., 2016; 2018). Omitting the dry period (van Hoeij et al., 2016), and shortening the dry period to $4 \mathrm{wk}$ without dry-cow therapy (DCT; Andrée O'Hara et al., 2019), increased SCC in the subsequent lactation compared with a dry period of 8 wk. More specifically, cows with no dry period had a greater proportion of chronic IMI, defined as a SCC $>200,000$ cells $/ \mathrm{mL}$ at the last test day before conventional dry-off and at the first test day after calving, and a lower proportion of cured IMI than cows with a $60-\mathrm{d}$ dry period $(50 \%$ chronic and $50 \%$ cured for $0-\mathrm{d}$ dry period vs. $8 \%$ chronic and $92 \%$ cured for 60-d dry period; van Hoeij et al., 2016). Moreover, the effect of dry-period length on SCC and mastitis incidence depended on prepartum individualcow characteristics including SCC elevations, average SCC during the complete lactation, or SCC at the last test day before dry-off (van Hoeij et al., 2016).

We hypothesized that customizing dry-period strategies for individual dairy cows could mitigate negative effects of shortening or omitting the dry period on milk production and udder health, and simultaneously retain benefits from improved energy balance, metabolic status, and fertility. In this study, we aimed to evaluate 2 decision trees to customize dry-period length and DCT based on parity, milk production, and SCC in late lactation. The effect of these decision trees on milk production, milk composition, SCC, BCS, BW, and treatments for disease was evaluated in the period from 8 wk before calving to 14 wk after calving. Moreover, effects of dry-period strategies on these same variables were assessed to understand the effect of decision trees.

\section{MATERIALS AND METHODS}

\section{Experimental Design, Animals, and Housing}

The experiment was conducted at the Dairy Campus research herd (Leeuwarden, the Netherlands) between July 2017 and December 2018. Cows were milked twice daily during lactation and housed in a freestall barn with concrete slatted floors and cubicles fitted with rubber mattresses covered in sawdust. In total, 195 Holstein-Friesian cows were selected before dry-off for the experiment based on being pregnant with a Holstein-Friesian calf, expected calving interval $<490 \mathrm{~d}$, milk yield $90 \mathrm{~d}$ before calving $>16 \mathrm{~kg} / \mathrm{d}$, and no clinical mastitis at enrollment. After enrollment, 12 cows were excluded due to pregnancy loss or late abortion and incorrect treatment. Cows were first blocked into groups of 3 based on similar parity ( 1 or $>1$ ), expected calving date, milk production in the previous lactation (for parity $>1$ ), and SCC at last test day before enrollment; subsequently, cows within blocks were randomly allocated to 1 of 3 decision trees (decision trees $\mathbf{C T}$, T1, T2; Figure 1).

In decision tree $\mathrm{CT}$, all cows were given a projected dry period of $60 \mathrm{~d}$ with selective DCT according to the standard management in the research herd. It should be noted that blanket DCT is no longer allowed in the Netherlands. It has been replaced by selective DCT using farm specific protocols, which are mostly based on late lactation SCC (i.e., animals with an SCC above threshold are treated with antibiotics; KNMvD, 2013; Scherpenzeel et al., 2016). In the Dairy Campus research herd, monthly SCC was available from routine test days as performed on commercial farms. Cows with a SCC $<150,000$ cells $/ \mathrm{mL}$ on the last test day before $67 \mathrm{~d}$ before expected calving were dried off without antibiotics with a teat seal (dry-period strategy 60TS; OrbeSeal, Zoetis, the Netherlands). Cows with a SCC $\geq 150,000$ cells $/ \mathrm{mL}$ were dried off with dry-cow antibiotics (dry-period strategy 60AB; Orbenin Extra Dry Cow, Zoetis, the Netherlands). To decrease milk production before dry-off, cows were switched to a dry-period ration $7 \mathrm{~d}$ before dry-off, and to once-daily milking $4 \mathrm{~d}$ before dry-off. The dry-period ration consisted of grass silage and corn silage, supplemented with wheat straw and concentrate. From 10 d before expected calving, cows received $1 \mathrm{~kg}$ of concentrate daily.

In decision tree $\mathrm{T} 1$, thresholds for SCC for selective DCT were taken from the Dutch guidelines from the Dutch royal society of veterinarians (KNMvD, 2013), which advise the use of dry-off antibiotics for cows in parity 1 with a SCC $\geq 150,000$ cells $/ \mathrm{mL}$ and for cows in parity $>1$ with a SCC $\geq 50,000$ cells $/ \mathrm{mL}$ before dry-off. 


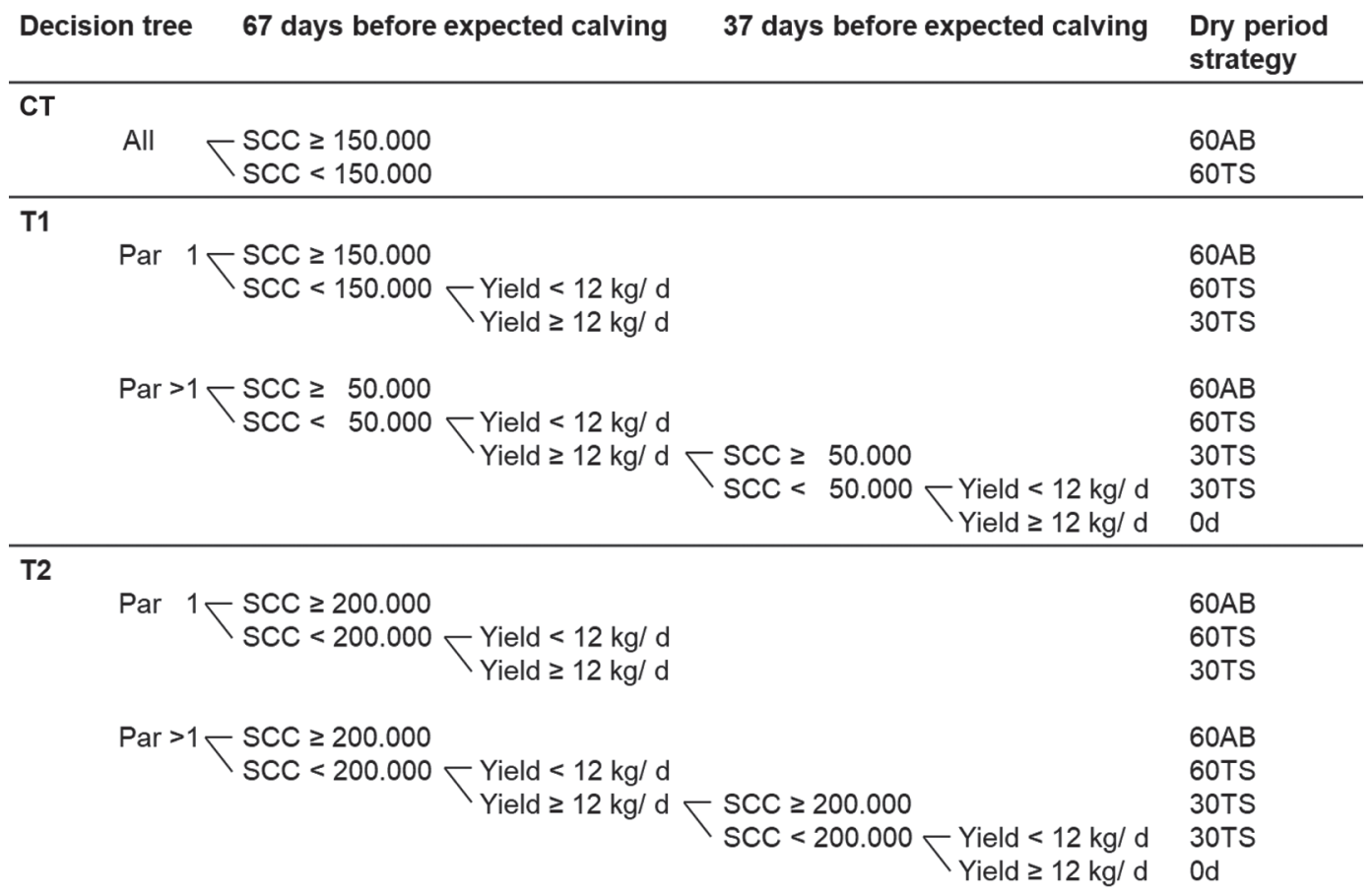

Figure 1. Visualization of the dry-period strategies applied under control (CT), treatment 1 (T1), and treatment 2 (T2) decision trees. Combinations of dry-period length of 60,30 , or $0 \mathrm{~d}$, and dry-cow therapy with antibiotics (AB) or teat seal (TS) depended on the SCC in cells/ $\mathrm{mL}$ on the last test day before the decision moment at 67 or $37 \mathrm{~d}$ before expected calving.

In decision tree $\mathrm{T} 2$, the threshold for $\mathrm{SCC}$ for selective DCT was increased to $\mathrm{SCC} \geq 200,000$ cells/mL before dry-off for all cows, based on thresholds for selective DCT that were encountered in practice. Decision moments occurred within the $\mathrm{T} 1$ and $\mathrm{T} 2$ trees at 67 and 37 $\mathrm{d}$ before the expected calving date (because cows were switched to a dry-period ration $7 \mathrm{~d}$ before dry-off). In the case of a cow in T1 or T2 with a SCC exceeding the respective threshold for DCT, she would be dried off with antibiotics and given a 60-d dry period as in CT (60AB). In the case of a cow with a SCC below the threshold, irrespective of parity, cows with a milk yield at the last test day lower than $12 \mathrm{~kg} / \mathrm{d}$ before the decision moment at $67 \mathrm{~d}$ before calving were subjected to a dry period of $60 \mathrm{~d}$ and dried off with a teat seal (i.e., without antibiotics), as in CT (60TS). These cows were considered not suitable to sustain lactation in the case of a short or no dry period. Cows with a milk yield above $12 \mathrm{~kg} / \mathrm{d}$ were not dried off for $60 \mathrm{~d}$, but were selected for a 30-d or 0-d dry period depending on their parity and milk production. In the case of parity 1 , cows were given a dry period of $30 \mathrm{~d}$ with a teat seal (dry-period strategy 30TS). This dry period was also preceded by a dry period ration from $7 \mathrm{~d}$ before dry-off, and to once-daily milking from $4 \mathrm{~d}$ before dry-off. Cows in parity 1 were disqualified from a $0-d$ dry period in this study because of a larger reduction in milk yield in the subsequent lactation than cows in parity $>1$ (Annen et al., 2004; Kok et al., 2017a,b). Parity $>1$ was given a dry period of $30 \mathrm{~d}$ in the case that SCC exceeded the threshold for dry-cow therapy or if yield was lower than $12 \mathrm{~kg} / \mathrm{d}$ at the re-evaluation at $37 \mathrm{~d}$ before expected calving (30TS), and no dry period (dry period strategy Od) if SCC remained below the threshold and yield remained above $12 \mathrm{~kg} / \mathrm{d}$.

\section{Measurements and Data Analysis}

Milk yield of lactating cows was recorded daily from $8 \mathrm{wk}$ before calving to $14 \mathrm{wk}$ after calving in a 40 -cow rotary milking parlor (GEA, Dusseldorf, Germany). Milk samples for fat, protein, lactose, and SCC analysis were collected weekly before calving and in wk 2, $4,6,8,10,12$, and 14 after calving (ISO 9622, ISO, 2013; Qlip, Zutphen, the Netherlands). Samples were analyzed as a pooled cow-composite sample collected during 2 morning and 2 afternoon milkings per cow per week (Tuesday afternoon, Wednesday morning, Wednesday afternoon, and Thursday morning). Lactating cows were weighed after each milking and BW was averaged per week; dry cows were walked through the milking parlor weekly for a BW measurement. Body 
condition score was measured on a scale from 1 to 5 by the same trained animal caretaker every 4 wk (Ferguson et al., 1994).

The outcome variables milk yield and composition, SCC, BW, and BCS were each analyzed separately for the periods prepartum (wk -8 to -1 relative to actual calving date) and postpartum (wk 1 to 14 after actual calving date) using mixed models [proc mixed (Littell et al., 1996) in SAS version 9.1; SAS Institute, Inc., Cary, NC] with cow as the repeated subject, using a first order autoregressive covariance structure to account for within-cow variation. Somatic cell counts were log-transformed before analysis. Each variable was analyzed using 2 different models. The first model included decision tree (CT, T1, T2), parity (1 or $>1$ before calving), week, and their interactions as fixed effects to evaluate the consequences of decision trees. The second model included 7 combinations of dry period strategies and parity class (par; 60AB par1, 60TS par1, 30TS par1, 60AB par >1, 60TS par $>1$, 30TS par $>1$, 0d par $>1$ ) and week as fixed effects. Dry-period strategy and parity class were not used as separate factors because cows in parity 1 were never subjected to the 0 -d dry period. Cows with missing values were kept in the analysis. All factors were retained in the models, irrespective of significance. In case of significant effects $(P<0.05)$, Bonferroni-adjustment was applied to $P$ values of pair-wise comparisons. Values were presented as least squares means and the largest standard error of the mean of the presented groups.

To evaluate whether high SCC had occurred during the study period, the SCC recorded at wk -10 or -9 prepartum was compared with the first SCC recorded between 10 and 24 DIM. Cows were considered to have a high SCC if SCC was $\geq 200,000$ cells $/ \mathrm{mL}$ (van Hoeij et al., 2016). Cows were categorized as having a chronic high SCC, healthy (SCC $<200,000$ cells/ $\mathrm{mL}$ prepartum and postpartum), having an elevated SCC postpartum (SCC $<200,000$ cells $/ \mathrm{mL}$ prepartum and $\mathrm{SCC} \geq 200,000$ cells $/ \mathrm{mL}$ postpartum), or having recovered (SCC $\geq 200,000$ cells/mL prepartum and SCC $<200,000$ cells/mL postpartum). The difference in incidence risks of high SCC among the 3 decision trees and among dry-period strategies was analyzed using a logistic regression model (PROC LOGISTIC), as described in van Hoeij et al. (2016). In brief, 2 separate binary models were run: one with high SCC prepartum and chronic high SCC (1) versus having recovered (0); the other with low SCC prepartum and having a new high SCC (1) versus staying healthy (0). All treatments of disease during the experiment were recorded by farm staff daily according to farm protocols (Dairy Campus, Leeuwarden, the Netherlands), and staff was not blinded for prepartum decision trees or dry-period strategies. Treatment events were registered daily based on treatments for disease, including ketosis, milk fever, mastitis, claw disorders, retained placenta, vaginal discharge, endometritis, cystic ovaries, and other diseases, and then summed per decision tree. The association between decision tree and the probability of being healthy versus having at least 1 disease was analyzed using a Pearson chi-squared test.

\section{RESULTS AND DISCUSSION}

\section{Distribution of Dry-Period Strategies Within Decision Trees}

In total, 183 cows were subjected to different dry-period lengths and selective DCT based on the respective decision trees, resulting in average realized dry-period lengths of $58 \mathrm{~d}, 47 \mathrm{~d}$, and $25 \mathrm{~d}$ for decision trees CT, $\mathrm{T} 1$, and T2, respectively. The distribution of cows over dry-period strategies per decision tree is visualized in Figure 2. Somatic cell count thresholds resulted in 38 out of 59 cows with a $60 \mathrm{AB}$ dry period in T1, compared with only 12 out of 61 cows in CT, and 11 out of 63 cows in T2 (i.e., $63 \%$ vs. $17 \%$ vs. $20 \%$ of all cows were dried off with antibiotics in decision trees T1, T2, and $\mathrm{CT}$ ). With the same threshold value (i.e., within CT and T2), more parity $>1$ cows qualified for $60 \mathrm{AB}$ than parity 1 cows, in accordance with previous research that more older cows had high SCC at dry-off than parity 1 cows (Scherpenzeel et al., 2016). Only cows with a SCC below the threshold for selective DCT qualified for a short or no dry period in T1 and T2 if their milk yield before the decision moment was above $12 \mathrm{~kg} / \mathrm{d}$. In T1, $36 \%$ of cows qualified for $30 \mathrm{TS}$ and $2 \%$ for $0 \mathrm{~d}$, mainly cows in parity 1 with a 30TS dry period; however, in T2, this was $51 \%$ for $30 \mathrm{TS}$ and $30 \%$ for $0 \mathrm{~d}$. In T2, 31 cows with parity $>1$ qualified for a short or no dry period and were re-evaluated at $37 \mathrm{~d}$ before expected calving. Of these 31 cows with parity $>1,19$ retained sufficient milk yield in late lactation and qualified for the 0d dry-period treatment.

\section{Milk Yield and Composition}

Milk yield of cows from 8 wk before calving to $14 \mathrm{wk}$ after calving was calculated per decision tree (Figure $3 \mathrm{~A}$ ) and per dry-period length per parity (Figure 3B).

Before Calving. In the 8 wk before calving, cows on average produced the least milk in $\mathrm{CT}$ and most in $\mathrm{T} 2$, with $\mathrm{T} 1$ being intermediate $(0.2$ vs. 3.9 vs. 7.1 $\mathrm{kg} / \mathrm{d}$ in $\mathrm{CT}$ vs. T1 vs. T2, Table 1 ). In CT, cows were planned to have a dry period of $60 \mathrm{~d}$, and most cows did not lactate in the $8 \mathrm{wk}$ before calving. As shown in Figure 3A, however, some milk was produced in wk 
-8 and -7 relative to (actual) calving because some cows calved a week or 2 before their expected calving date, and consequently had a dry period of about 7 wk. Cows in decision tree T2 produced more milk than cows in decision tree $\mathrm{T} 1$ due to lower thresholds for selective DCT, which assigned more cows to the $60 \mathrm{AB}$ in T1. Average milk production was $12.4 \mathrm{~kg} / \mathrm{d}$ for cows in parity $>1$ with $0 \mathrm{~d}, 7.1$ for cows with $30 \mathrm{TS}$ in parity 1 , and $6.5 \mathrm{~kg} / \mathrm{d}$ for cows with $30 \mathrm{TS}$ in parity $>1$ (Table 2). A similar study corroborated with these results, and reported average productions of $13.8 \mathrm{~kg} / \mathrm{d}$ and $7.7 \mathrm{~kg} / \mathrm{d}$ for cows with a dry period of 0 or $30 \mathrm{~d}$ in the $8 \mathrm{wk}$ before calving, respectively (van Knegsel et al., 2014). Cows in parity 1 had higher additional yields in case of no dry period than cows in parity $>1$ (van Knegsel et al., 2014).

The milk composition did not differ between the 3 decision trees or between the dry-period strategies. Due to the different milk yields, however, the production of lactose, fat, and protein before calving was greatest for decision tree $\mathrm{T} 2$ and negligible for $\mathrm{CT}$, with $\mathrm{T} 1$ being intermediate.

After Calving. In the first 14 wk after calving, average milk yield of cows was $3.0 \mathrm{~kg} / \mathrm{d}$ lower in decision tree $\mathrm{T} 1$ and $4.8 \mathrm{~kg} / \mathrm{d}$ lower in decision tree $\mathrm{T} 2$ than in decision tree CT (Table 3). Lactose and fat content did not differ between the 3 decision trees, whereas protein content was greater for cows in $\mathrm{T} 1$ and $\mathrm{T} 2$ than for cows in CT. These results can be explained by the lower milk yield and higher protein content of cows with a 0-d dry period, compared with cows with a 60-d dry period, and intermediate values for the 30-d dry period (Table 4). In total, the lower yield resulted in a lower average lactose, fat, and protein production for cows in decision trees $\mathrm{T} 1$ and $\mathrm{T} 2$ than for cows in decision tree CT.

The lower average milk yield in decision trees $\mathrm{T} 1$ and $\mathrm{T} 2$ compared with decision tree $\mathrm{CT}$ was caused by the lower milk yields of cows with 30TS and 0d compared with cows with $60 \mathrm{AB}$ and 60TS of the same parity class (Table 4). The use of antibiotics (60AB) versus
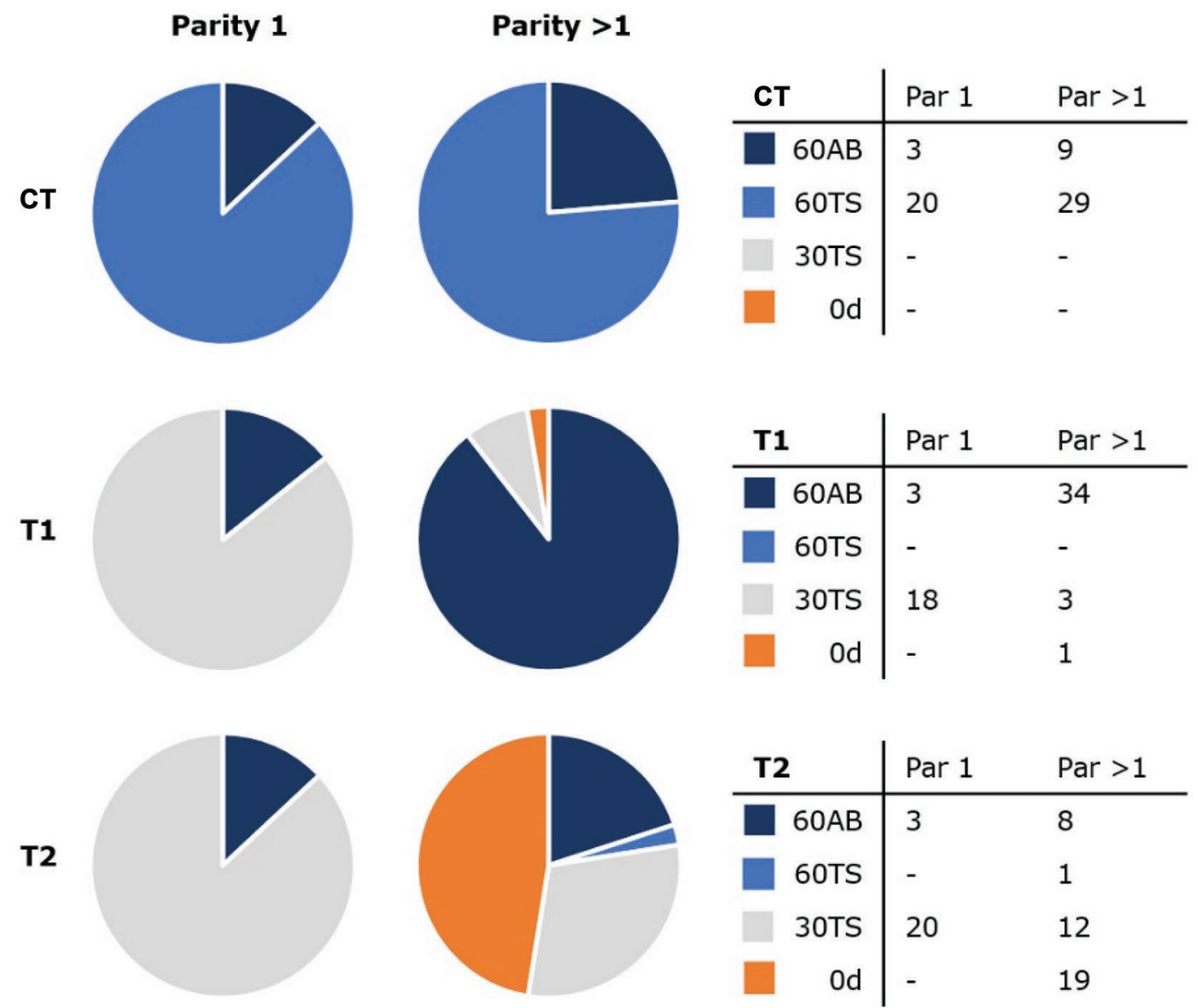

8
1
12
19

Figure 2. Distribution of cows within decision trees over different dry-period strategies. $\mathrm{CT}=$ control; $\mathrm{T} 1=$ decision tree 1 ; $\mathrm{T} 2=$ decision tree $2.60 \mathrm{AB}=60$-d dry period with dry-cow antibiotics; $60 \mathrm{TS}=60$-d dry period with teat seal; 30TS $=30-\mathrm{d}$ dry period with teat seal; 0d $=$ 0 -d dry period. Par = parity. 
Table 1. Average milk yield, milk composition, SCC, BW, and BCS of cows per decision tree in the 8 wk before calving; values represent LSM with maximum SEM

\begin{tabular}{|c|c|c|c|c|c|c|c|c|c|c|}
\hline \multirow[b]{2}{*}{ Item } & \multicolumn{3}{|c|}{ Decision tree ${ }^{1}$} & \multirow[b]{2}{*}{ SEM } & \multicolumn{6}{|c|}{$P$-value ${ }^{2}$} \\
\hline & $\mathrm{CT}$ & $\mathrm{T} 1$ & $\mathrm{~T} 2$ & & Tree & Parity & Week & $\mathrm{T} \times \operatorname{Par}$ & $\mathrm{T} \times \mathrm{W}$ & Par $\times W$ \\
\hline $\mathrm{N}$ cows $^{3}$ & 61 & 59 & 63 & & & & & & & \\
\hline Lactose $(\%)$ & $\mathrm{NA}^{4}$ & 4.48 & 4.46 & 0.06 & 0.80 & 0.45 & $\mathrm{NM}^{5}$ & 0.12 & NM & NM \\
\hline Fat $(\%)$ & NA & 5.16 & 5.07 & 0.17 & 0.64 & 0.65 & NM & 0.95 & NM & NM \\
\hline Protein (\%) & NA & 4.11 & 4.22 & 0.16 & 0.53 & 0.01 & NM & 0.55 & NM & NM \\
\hline Protein $(\mathrm{kg} / \mathrm{d})$ & $0.01^{\mathrm{a}}$ & $0.15^{\mathrm{b}}$ & $0.30^{\mathrm{c}}$ & 0.02 & $<0.01$ & 0.20 & $<0.01$ & $<0.01$ & $<0.01$ & $<0.01$ \\
\hline BW (kg) & 743 & 731 & 734 & 6.1 & 0.99 & $<0.01$ & 0.02 & 0.95 & 0.22 & 0.19 \\
\hline $\mathrm{BCS}^{6}$ & 3.2 & 3.1 & 3.0 & 0.07 & 0.54 & $<0.01$ & 0.41 & 0.35 & 0.51 & 0.12 \\
\hline $\operatorname{SCC}^{7}(\times 1,000$ cells $/ \mathrm{mL})$ & NA & 107 & 108 & - & 0.96 & 0.61 & NM & 0.06 & NM & NM \\
\hline
\end{tabular}

${ }^{\mathrm{a}-\mathrm{c}}$ Values in the same row with different superscripts are significantly different $(P<0.05)$.

${ }^{1} \mathrm{CT}=$ control; $\mathrm{T} 1=$ decision tree $1 ; \mathrm{T} 2=$ decision tree 2.

${ }^{2} \mathrm{~T}=$ decision tree; Par $=$ parity class; $\mathrm{W}=$ week.

${ }^{3}$ Reflects all cows per decision tree. For lactose, fat, and protein content (\%) and SCC, only cows with a 30-d or 0-d dry period were included (i.e., no cows in decision tree CT, 22 cows in T1, and 51 cows in T2).

${ }^{4} \mathrm{NA}=$ not available.

${ }^{5} \mathrm{NM}=$ not included in the model.

${ }^{6} \mathrm{BCS}$ was measured on a scale from 1 to 5 and was assessed per month instead of week.

${ }^{7} P$-values are based on analysis of log-transformed values of SCC; SEM is not applicable.

teat seal (60TS) at dry-off did not affect milk yield or composition of cows with a dry period of $60 \mathrm{~d}$.

A meta-analysis estimated average reductions in milk production after calving of $1.4 \mathrm{~kg} / \mathrm{d}$ and $5.9 \mathrm{~kg} / \mathrm{d}$ for cows with a short (i.e., 28-35 d) or no dry period, respectively, compared with a conventional dry period of 8 wk (van Knegsel et al., 2013). Later studies reported that milk reductions in the 12 or 14 wk after calving amounted to $6.7 \mathrm{~kg} / \mathrm{d}$ (Andrée O'Hara et al., 2018) or $4.6 \mathrm{~kg} / \mathrm{d}$ (van Knegsel et al., 2014) for a short dry pe- riod, compared with a conventional dry period of $8 \mathrm{wk}$ or $60 \mathrm{~d}$. Omitting of the dry period resulted in a milk reduction of $10.6 \mathrm{~kg} / \mathrm{d}$ for the first 14 wk of lactation (van Knegsel et al., 2014) and $4.0 \mathrm{~kg} / \mathrm{d}$ for $305-\mathrm{d}$ ECM yield (Köpf et al., 2014), compared with a conventional dry period of about 8 wk. In the current study, cows were balanced for parity between decision trees CT, T1, and $\mathrm{T} 2$, but they were deliberately assigned to the different dry-period strategies based on the different decision trees. The smaller yield reduction for cows with
A.

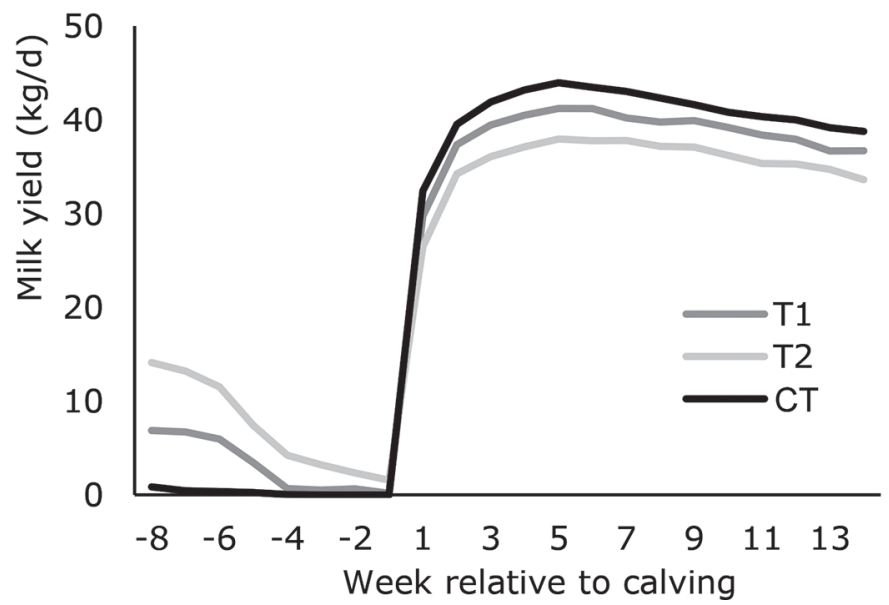

B.

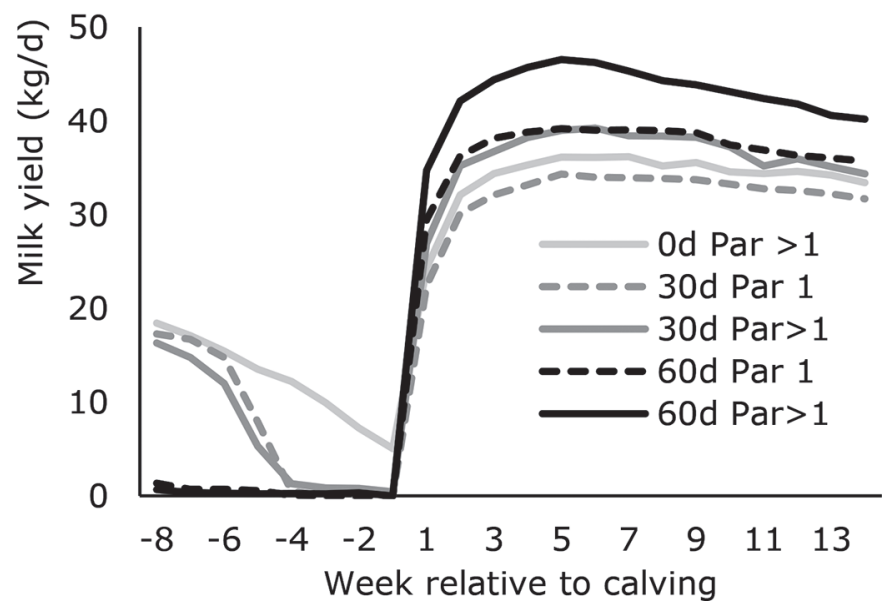

Figure 3. Milk yield of cows $(\mathrm{n}=183)$ per decision tree $(\mathrm{A})$ and per dry-period length per parity class $(\mathrm{B})$. CT $=$ control $(\mathrm{n}=61)$; T1 $=$ decision tree $1(\mathrm{n}=59)$; T2 = decision tree $2(\mathrm{n}=63) ; 0 \mathrm{~d}=$ no dry period $(\mathrm{n}=20) ; 30 \mathrm{~d}=$ dry period of $30 \mathrm{~d}(\mathrm{n}=38$ for parity 1 and $\mathrm{n}=15$ for parity $>1) ; 60 \mathrm{~d}=$ dry period of $60 \mathrm{~d}(\mathrm{n}=29$ for parity 1 and $\mathrm{n}=81$ for parity $>1)$. Par $=$ parity. 
Table 2. Average milk yield, milk composition, SCC, BW, and BCS of cows per dry-period strategy ${ }^{1}$ in the 8 wk before calving; values represent LSM with maximum SEM

\begin{tabular}{|c|c|c|c|c|c|c|c|c|c|c|c|}
\hline \multirow{2}{*}{ Item } & \multicolumn{7}{|c|}{ Dry-period strategy $^{1}$} & \multirow{2}{*}{ SEM } & \multirow{2}{*}{\multicolumn{3}{|c|}{$P$-value ${ }^{2}$}} \\
\hline & \multicolumn{3}{|c|}{ Parity 1} & \multicolumn{4}{|c|}{ Parity $>1$} & & & & \\
\hline $\mathrm{N}$ cows & 9 & 20 & 38 & 51 & 30 & 15 & 20 & & & & \\
\hline Milk yield (kg/d) & $0.1^{\mathrm{a}}$ & $0.5^{\mathrm{a}}$ & $7.1^{\mathrm{b}}$ & $0.5^{\mathrm{a}}$ & $0.0^{\mathrm{a}}$ & $6.5^{\mathrm{b}}$ & $12.4^{\mathrm{c}}$ & 0.9 & $<0.01$ & $<0.01$ & $<0.01$ \\
\hline Lactose $(\%)$ & $\mathrm{NA}^{3}$ & NA & 4.50 & NA & NA & 4.42 & 4.38 & 0.06 & 0.12 & $\mathrm{NM}^{4}$ & NM \\
\hline Lactose (kg/d) & $0.00^{\mathrm{a}}$ & $0.02^{\mathrm{a}}$ & $0.33^{\mathrm{b}}$ & $0.02^{\mathrm{a}}$ & $0.00^{\mathrm{a}}$ & $0.30^{\mathrm{b}}$ & $0.57^{\mathrm{c}}$ & 0.04 & $<0.01$ & $<0.01$ & $<0.01$ \\
\hline Fat $(\mathrm{kg} / \mathrm{d})$ & $0.00^{\mathrm{a}}$ & $0.03^{\mathrm{a}}$ & $0.36^{\mathrm{b}}$ & $0.02^{\mathrm{a}}$ & $0.00^{\mathrm{a}}$ & $0.34^{\mathrm{b}}$ & $0.63^{\mathrm{c}}$ & 0.04 & $<0.01$ & $<0.01$ & $<0.01$ \\
\hline Protein $(\mathrm{kg} / \mathrm{d})$ & $0.00^{\mathrm{a}}$ & $0.02^{\mathrm{a}}$ & $0.28^{\mathrm{b}}$ & $0.02^{\mathrm{a}}$ & $0.00^{\mathrm{a}}$ & $0.27^{\mathrm{b}}$ & $0.55^{\mathrm{c}}$ & 0.03 & $<0.01$ & $<0.01$ & $<0.01$ \\
\hline BW $(\mathrm{kg})$ & $664^{\mathrm{a}}$ & $674^{\mathrm{a}}$ & $669^{\mathrm{a}}$ & $768^{\mathrm{b}}$ & $786^{\mathrm{b}}$ & $764^{\mathrm{b}}$ & $774^{\mathrm{b}}$ & 17 & $<0.01$ & $<0.01$ & 0.30 \\
\hline $\mathrm{BCS}^{5}$ & $3.0^{\mathrm{ab}}$ & $2.7^{\mathrm{a}}$ & $2.8^{\mathrm{a}}$ & $3.3^{\mathrm{b}}$ & $3.4^{\mathrm{b}}$ & $3.1^{\mathrm{ab}}$ & $3.1^{\mathrm{ab}}$ & 0.19 & $<0.01$ & 0.16 & 0.07 \\
\hline $\mathrm{SCC}^{6}(\times 1,000$ cells $/ \mathrm{mL})$ & NA & NA & 101 & NA & NA & 126 & 137 & - & 0.21 & NM & NM \\
\hline
\end{tabular}

${ }^{a-c}$ Values in the same row with different superscripts are significantly different $(P<0.05)$.

${ }^{1} 60 \mathrm{AB}=60$-d dry period with dry-cow antibiotics; $60 \mathrm{TS}=60$-d dry period with teat seal; 30TS $=30$-d dry period with teat seal; 0d $=0$-d dry period.

${ }^{2} \mathrm{DP} \_\mathrm{P}=$ dry period class $\times$ parity class; $\mathrm{W}=$ week.

${ }^{3} \mathrm{NA}=$ not available.

${ }^{4} \mathrm{NM}=$ not included in the model.

${ }^{5} \mathrm{BCS}$ was measured on a scale from 1 to 5 and was assessed per month instead of week.

${ }^{6} P$-values are based on analysis of log-transformed values of SCC; SEM is not applicable.

0d treatment in this study compared with our previous study might be explained by the fact that only cows in parity $>1$ could qualify for a 0-d dry-period strategy: cows in parity 1 had a more severe reduction in milk yield following the 0d treatment, as well as a lower milk yield than cows in parity $>1$. In contrast, the larger yield reduction for cows with the 30TS treatment is a consequence of the large proportion of parity 1 cows in this group $(38 / 53,72 \%)$ and possibly also by the fact that cows in parity $>1$ that retained a higher milk yield in late lactation were assigned to the 0d dry and not to the 30TS strategy.

\section{Body Weight and BCS}

Body weight and BCS did not differ among the 3 decision trees or among dry-period strategies per parity class in the 8 wk before calving or the 14 wk after calv-

Table 3. Average milk yield, milk composition, SCC, BW, and BCS of cows per decision tree in 14 wk after calving; values represent LSM with maximum SEM

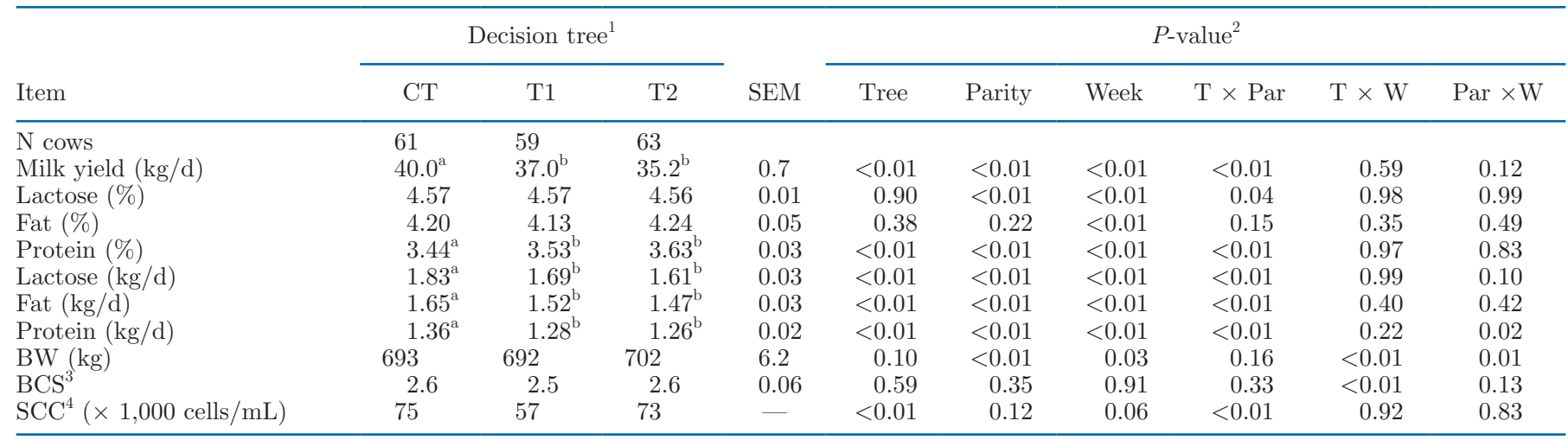

\footnotetext{
${ }^{a-c}$ Values in the same row with different superscripts are significantly different $(P<0.05)$.

${ }^{1} \mathrm{CT}=$ control; $\mathrm{T} 1=$ decision tree $1 ; \mathrm{T} 2=$ decision tree 2.

${ }^{2} \mathrm{~T}=$ decision tree; Par $=$ parity class; $\mathrm{W}=$ week.

${ }^{3} \mathrm{BCS}$ was measured on a scale from 1 to 5 and was assessed per month instead of week.

${ }^{4} P$-values are based on analysis of log-transformed values of SCC; SEM is not applicable.
} 


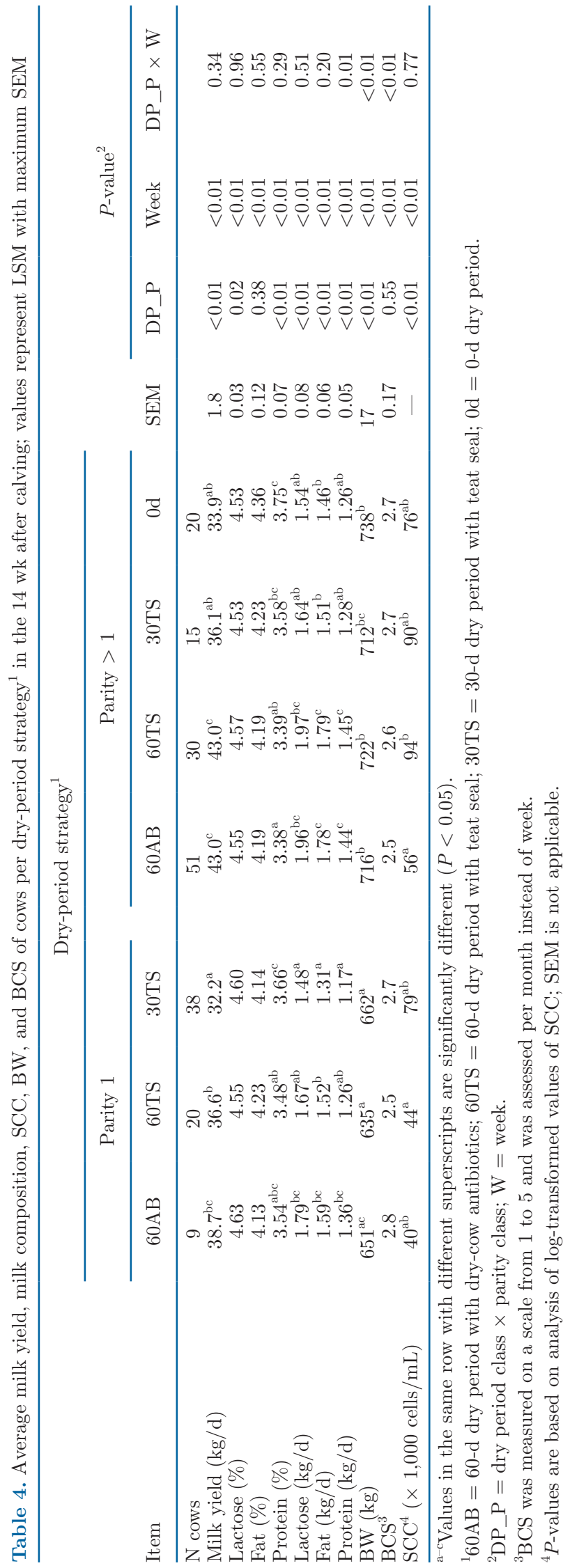

ing. However, in the first $14 \mathrm{wk}$ after calving, a time by decision tree interaction and a time by dry-period strategy were found, indicating that the change in BCS and BW over time differed among decision trees (Table 3 ) and dry-period strategies (Table 4). Recovery of BW in the postpartum period was greater for $\mathrm{T} 2$ than for CT and T1 (Figure 4A), which is primarily due to the increase in BW in 0d cows (Figure 4B). Increased BW gain in early lactation could indicate that cows have a better energy balance in early lactation. Also, previous studies found an improved energy balance in early lactation when no dry period was applied, which resulted in a greater BW gain after calving (Rastani et al., 2005; van Hoeij et al., 2017).

\section{Somatic Cell Count}

In the 8 wk before calving, SCC did not differ between cows that were still lactating among the different decision trees or dry-period strategies. Numerically, the average SCC was greater in the $60 \mathrm{AB}$ treatment, which can be explained by the selection criteria for DCT (i.e., cows with SCC above the threshold qualified for antibiotics at dry-off). In the first 14 wk after calving, the average SCC was lower for cows in $\mathrm{T} 1$ than for cows in T2 and CT (Table 3). The lower SCC postpartum might be explained by the higher use of antibiotics at dry-off in T1 (63\%) than in T2 (17\%) and CT $(20 \%$; Figure 2), which is in line with earlier work on selective use of DCT (Scherpenzeel et al., 2014).

In the 14 wk after calving, for parity $>1$ cows, $60 \mathrm{AB}$ cows had a lower SCC than 60TS, but 30TS or 0d was not different from the 60AB or 60TS (Table 4). For parity 1 cows, dry-period strategy did not affect SCC in the first $14 \mathrm{wk}$ after calving. In earlier studies, omitting the dry period (Steeneveld et al., 2013; van Hoeij et al., 2016) and shortening the dry period without dry-cow antibiotics (Andrée O'Hara et al., 2019) increased SCC in the subsequent lactation, which was attributed to either omitting use of dry-cow antibiotics or a reduction in milk yield after shortening or omitting of the dry period in these studies. In the current study, milk yield was reduced after shortening and omitting of the dry period, but SCC was not affected compared with a 60-d dry period. This discrepancy between our study and earlier work might be related to selection of high SCC cows for a dry-period strategy of $60 \mathrm{~d}$ dry and use of dry-cow antibiotics, while earlier studies blocked cows for SCC and randomly assigned them to different dry-period lengths (Rastani et al., 2005; van Hoeij et al., 2016; Andrée O'Hara et al., 2019).

To assess whether elevations in SCC had occurred during the study period, udder health was evaluated using SCC recorded at wk -10 or -9 prepartum, and 
Table 5. Evaluation of changes in SCC from before dry-period management to early lactation for cows in different decision trees

\begin{tabular}{|c|c|c|c|c|c|c|c|c|}
\hline \multirow[b]{3}{*}{ Item } & \multicolumn{6}{|c|}{ Decision tree ${ }^{1}$} & \multirow[b]{2}{*}{ Total } & \multirow[b]{3}{*}{$\%$} \\
\hline & \multirow{2}{*}{$\begin{array}{l}\text { CT } \\
\text { No. }\end{array}$} & \multirow[b]{2}{*}{$\%$} & \multirow{2}{*}{$\frac{\mathrm{T} 1}{\mathrm{No} .}$} & \multirow[b]{2}{*}{$\%$} & \multirow{2}{*}{$\begin{array}{l}\text { T2 } \\
\text { No. }\end{array}$} & \multirow[b]{2}{*}{$\%$} & & \\
\hline & & & & & & & No. & \\
\hline \multicolumn{9}{|c|}{ High SCC prepartum $^{2}$} \\
\hline Chronic & 3 & 7.0 & 1 & 2.3 & 1 & 2.1 & 5 & 3.7 \\
\hline Recovered & 3 & 7.0 & 5 & 11.4 & 8 & 17.0 & 16 & 11.9 \\
\hline \multicolumn{9}{|c|}{ Low SCC prepartum } \\
\hline Elevation & 3 & 7.0 & 4 & 9.1 & 8 & 17.0 & 15 & 11.2 \\
\hline Healthy & 34 & 79.1 & 34 & 77.3 & 30 & 63.8 & 98 & 73.1 \\
\hline Total & 43 & 100 & 44 & 100 & 47 & 100 & 134 & 100 \\
\hline
\end{tabular}

SCC was recorded between 10 and 24 DIM. Due to technical difficulties, SCC data of both periods was available for only 134 of the 183 cows. Decision tree did not affect the probability that cows had a chronic high SCC versus recovered SCC, nor the probability that cows had an elevated SCC versus a low SCC after calving (Table 5), but animal numbers were small. There was an effect of dry-period strategy on the probability that cows had an elevated SCC versus a low SCC after calving $(P<0.05$; Table 6$)$. Cows with a 30TS dryperiod strategy had a greater probability of an elevated SCC after calving than 60AB cows (odds ratio: 10.77; 95\% CI: 1.29-90.06). Due to the selective DCT, cows with a high SCC $(>200,000$ cells $/ \mathrm{mL})$ were never assigned to 0d. Between the first decision moment (at the last test day $-67 \mathrm{~d}$ before expected calving date) and the second decision moment (at $-37 \mathrm{~d}$ before expected calving date), 8 of the cows not assigned to $60 \mathrm{AB}$ had developed an elevated SCC. According to the decision tree, these cows were dried off for $30 \mathrm{~d}$ without antibiotics. From these 8 cows in 30TS that had a high SCC before calving, 7 had spontaneously recovered to a low SCC in early lactation.

\section{Treatment for Diseases}

All treatment for clinical diseases during the experimental period were recorded and scored as ketosis, milk fever, mastitis, claw disorders, retained placenta, vaginal discharge, endometritis, cystic ovaries, and other (Table 7; Appendix Table A1). In total, 134 occurrences of treatment were recorded in the first 14 wk after calving, amounting to 49,33 , and 52 treatments of disease in T1, T2, and CT, respectively. The probability of hav-
A.

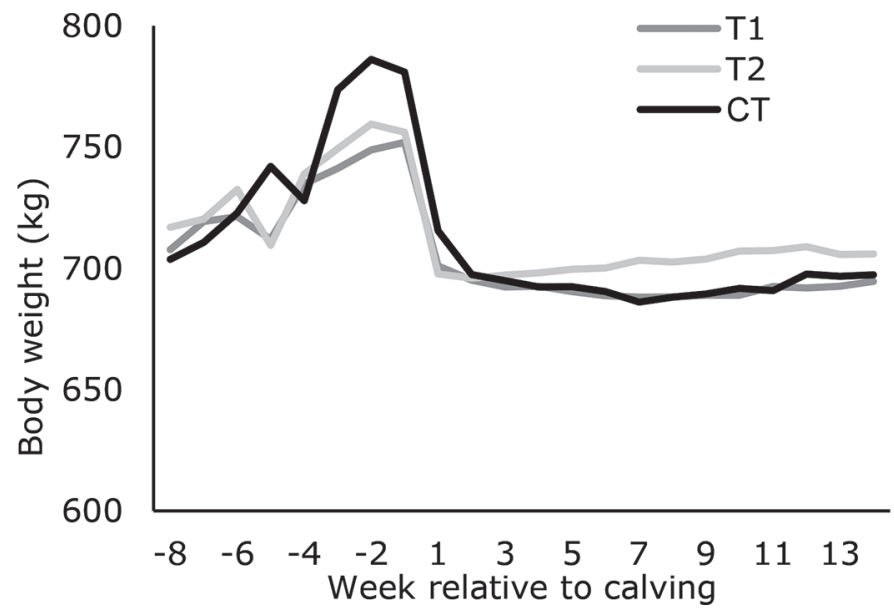

B.

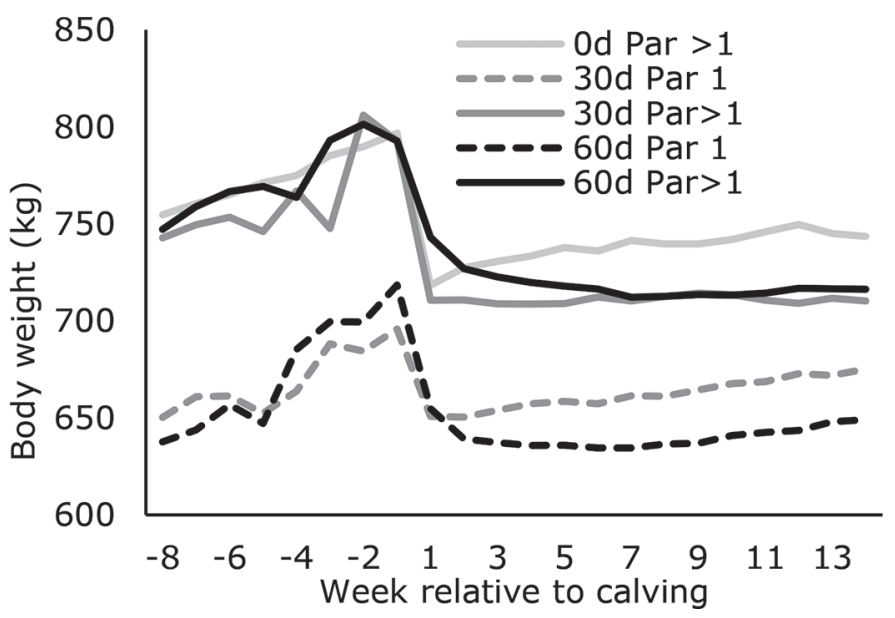

Figure 4. Body weight of cows $(\mathrm{n}=183)$ per decision tree $(\mathrm{A})$ and per dry-period length per parity class $(\mathrm{B})$. CT $=$ control $(\mathrm{n}=61)$; $\mathrm{T} 1$ $=$ decision tree $1(\mathrm{n}=59) ; \mathrm{T} 2=$ decision tree $2(\mathrm{n}=63) ; 0 \mathrm{~d}=$ no dry period $(\mathrm{n}=20) ; 30 \mathrm{~d}=$ dry period of $30 \mathrm{~d}(\mathrm{n}=38$ for parity 1 and $\mathrm{n}=$ 15 for parity $>1) ; 60 \mathrm{~d}=$ dry period of $60 \mathrm{~d}(\mathrm{n}=29$ for parity 1 and $\mathrm{n}=81$ for parity $>1)$. Par $=$ parity. 
Table 6. Evaluation of changes in SCC from before dry-period management to early lactation, for cows with different dry-period strategies

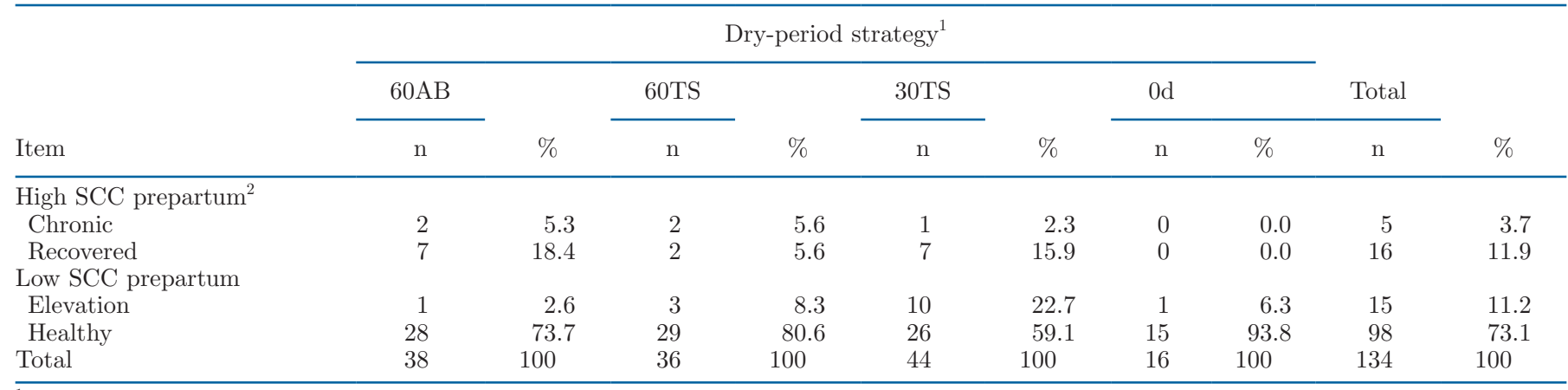

${ }^{1} 60 \mathrm{AB}=60$-d dry period with dry-cow antibiotics; $60 \mathrm{TS}=60$-d dry period with teat seal; 30TS $=30$-d dry period with teat seal; 0d $=0$-d dry period.

${ }^{2} \mathrm{SCC}>200,000$ cells $/ \mathrm{mL}$ at wk -10 or -9 relative to calving.

ing no treatment was associated with decision tree $(P$ $=0.04)$, but posthoc comparisons were not significant. Numerically, however, fewest treatments were recorded in decision tree T2. Decision tree T2 is characterized by a larger share of short and omitted dry periods for parity $>1$ than CT and T1 (Figure 2). The effect of short and no dry periods on occurrence of specific diseases remains inconclusive due to the limited animal numbers and variation among studies (van Knegsel et al., 2013). However, short and no dry periods lower milk yield and improved the energy balance in early lactation (Rastani et al., 2005; Andrée O'Hara et al., 2018) as well as reduce plasma nonesterified fatty acids and, in some studies, plasma BHB concentrations in early lactation (Andersen et al., 2005; Klusmeyer et al., 2009; Chen et al., 2015a). Moreover, although no cows were treated for clinical ketosis in this study, even subclinical ketosis (i.e., definition Keto-Test $\geq 100 \mu \mathrm{mol} / \mathrm{L}$ ) has been found to increase the odds of other diseases in early lactation (Berge and Vertenten, 2014). The better metabolic status that might be expected in decision

Table 7. Treatment events ${ }^{1}$ of cows in the first $14 \mathrm{wk}$ after calving for cows in different decision $\operatorname{trees}^{2}$ (T1, T2, or CT)

\begin{tabular}{lrrrr}
\hline Item & T1 & T2 & CT & Total \\
\hline Ketosis & 0 & 0 & 0 & 0 \\
Milk fever & 6 & 3 & 3 & 12 \\
Mastitis & 4 & 5 & 5 & 14 \\
Claw disorders & 9 & 3 & 8 & 20 \\
Retained placenta & 4 & 4 & 6 & 14 \\
Vaginal discharge & 11 & 8 & 15 & 34 \\
Endometritis & 9 & 8 & 7 & 24 \\
Cystic ovaries & 6 & 1 & 4 & 11 \\
Other & 0 & 1 & 4 & 5 \\
Total treatment events $(n)$ & 49 & 33 & 52 & 134 \\
Cows without treatments (n) & 27 & 40 & 26 & 93 \\
Total number of cows $(n)$ & 59 & 63 & 61 & 183 \\
\hline
\end{tabular}

${ }^{1}$ Based on treatments for disease.

${ }^{2} \mathrm{CT}=$ control; $\mathrm{T} 1=$ decision tree $1 ; \mathrm{T} 2=$ decision tree 2. tree T2 due to the large share of short and omitted dry periods might explain the numerically lower number of treatments for disease.

\section{Practical Effect of Customized Dry-Period Strategies}

To evaluate economic consequences of the customized dry-period strategies, one should consider changes in revenues from milk as well as changes in costs for drycow antibiotics and treatment of diseases. Compared with CT, T1 resulted in an increased use of dry-cow antibiotics ( $63 \%$ vs. $20 \%$ of cows) and a similar number of treatments per cow (0.83 vs. 0.85). Compared with CT, T2 resulted in a similar use of dry-cow antibiotics $(17 \%$ vs. $20 \%$ of cows) and a lower number of treatments per cow $(0.52$ vs. 0.85$)$. In case of milk revenues, it should be kept in mind that the period from $8 \mathrm{wk}$ before until 14 wk after calving does not grasp the full effects of different decision trees and dry-period strategies on lactation production (Kok et al., 2016). The reduced milk production in decision trees $\mathrm{T} 1$ and $\mathrm{T} 2$ compared with decision tree $\mathrm{CT}$ in the $14 \mathrm{wk}$ after calving will likely persist in the rest of the lactation (Schlamberger et al., 2010; Chen et al., 2016), and is expected to continue with differences in milk yield later in lactation, and therefore to result in net milk losses for both T1 and T2 compared with CT. At the same time, differences in number of treatments for disease and energy balance in early lactation could affect health beyond wk 14 in lactation, fertility, and probability of culling, which were not assessed in the current study. The largest benefits for fertility and metabolic status might be expected for T2 due to the largest share of cows with a 0-d dry period (Rastani et al., 2005; Andersen et al., 2005; Chen et al., 2015b). Cows with a 0-d dry period were previously found to have improved resumption of ovarian cyclicity compared with cows with a dry period of $60 \mathrm{~d}$ (Chen et al., 2015b), as well as fewer days to 
first ovulation, a greater first-service conception rate, and fewer days open than cows with standard (56 d) dry period (Gümen et al., 2005). Regarding metabolic status, cows with a 0-d dry period had lower plasma nonesterified fatty acid concentrations, higher plasma glucose, and better energy balance in early lactation than cows with a short or standard dry period (Andersen et al., 2005; Rastani et al., 2005; van Knegsel et al., 2014). Previously, considerably lower treatment costs were found to compensate for reduced milk revenues over the complete lactation in an experiment with continuous milking versus a standard dry period of $56 \mathrm{~d}$ (Köpf et al., 2014).

Short and no dry periods, but also customized dryperiod lengths, are applied by some Dutch dairy farmers (Steeneveld et al., 2013; Kok et al., 2016). In our earlier study (Steeneveld et al., 2013), 11 commercial farms that deliberately and voluntarily shortened or omitted the dry period for (part of) their cows were monitored. Six of these 11 farms applied an individual-cow approach and had different dry-period lengths within 1 herd. Moreover, the current situation with guidelines from the Dutch royal society of veterinarians for use of dry-cow antibiotics (KNMvD, 2013; Scherpenzeel et al., 2016), which were developed when the Dutch government requested the livestock sector to reduce antibiotic use in livestock, was a further incentive for farmers to consider an individual-cow approach for drycow strategies. When guidelines stimulate farmers to use only dry-cow antibiotics for cows with a high SCC, there are opportunities to reconsider dry-period length for the low-SCC cows because a withdrawal period for meat and milk after antibiotic use does not have to be considered, and drying off at lower milk yield would be beneficial for udder health of high-producing cows. As a result, an individual-cow approach for dry-cow management is currently practiced at Dutch dairy farms, at least for use of dry-cow antibiotics (Vanhoudt et al., 2018) as well as for dry-period length (Steeneveld et al., 2013).

Apart from limitations on use of dry-cow antibiotics, farmers' motivations to reduce dry-period length included that they perceive an improved fertility and health status of their cows, and that they value the ease of labor with fewer incidences of regrouping (Heeren et al., 2014) and no need for dry-cow ration preparation or dry-off procedures. Although it is clear that shortening or omitting the dry period in most instances will not yield extra milk revenues for the farmer (Kok et al., 2017b), these strategies might be used as riskmanagement strategies, to prevent dry-off at a high milk production, or to ease the transition period for some cows. The decision tree in the current study was based on cow characteristics that are readily available on commercial farms at the moment that a decision for a customized dry-period strategy is made. Farms in the Netherlands generally have a 4 - to 6 -wk interval for test days that provides milk yield, fat, protein and lactose content, and SCC of individual cows. In the current decision trees, the cow characteristics were parity, milk yield level, and SCC. In the future, other characteristics might be explored, such as BCS, disease history (e.g., elevations in SCC), and genotype (Kok et al., 2019). Moreover, the threshold for selective DCT might be reconsidered in the future (Scherpenzeel et al., 2014). Our study indicates that a low SCC threshold for selective DCT, such as applied for parity $>1$ in decision tree T1, makes it nearly impossible to apply short and no dry periods (Figure 2). A higher threshold for SCC, such as applied in decision tree $\mathrm{T} 2$, had only limited effects on the number of cows that were treated with antibiotics compared with decision tree $\mathrm{CT}$, and thus enabled the application of short and no dry periods. This higher threshold of 200,000 cells/mL was based on thresholds for selective DCT that were encountered in practice.

\section{CONCLUSIONS}

Customizing dry period strategies (dry-period length and antibiotic use) for cows using decision trees based on parity, milk production, and SCC in late lactation reduced milk losses due to short or no dry periods compared with applying the same dry-period length across the whole herd, and increased the proportion of healthy cows in early lactation. A short dry period of $30 \mathrm{~d}$ with a teat seal increased SCC in early lactation compared with a dry period of $60 \mathrm{~d}$ with antibiotics. The threshold value for SCC to apply selective DCT determined whether cows could qualify for short or no dry periods, and increasing the threshold greatly increased the number of cows for these dry-period strategies. Considering the complete lactation, shortening and omitting the dry period are expected to reduce milk revenues, but based on the current experiment with customized dry-period lengths, this might be financially compensated by reduced disease costs.

\section{ACKNOWLEDGMENTS}

The authors thank DairyNL (Zuivel-NL, Zoetermeer, the Netherlands; organization of the Dutch dairy supply chain) and the Dutch Ministry of Economic Affairs (EZ, The Hague, the Netherlands) for financing this study. This study is part of the Public-Private Partnership "Sustainable Dairy Chain" (Duurzame Zuivelketen; the Netherlands). The authors also thank staff of the Dairy Campus (Leeuwarden, the Netherlands) and 
Theo Lam (Utrecht University, the Netherlands) and Roselinde Goselink (Wageningen Livestock Research, Wageningen, the Netherlands) for their technical support and involvement in the experiment. The authors state that they have no conflict of interest.

\section{REFERENCES}

Andersen, J. B., T. G. Madsen, T. Larsen, K. L. Ingvartsen, and M. O. Nielsen. 2005. The effects of dry period versus continuous lactation on metabolic status and performance in periparturient cows. J. Dairy Sci. 88:3530-3541. https://doi.org/10.3168/jds.S0022 $-0302(05) 73038-1$.

Andrée O'Hara, E., R. Båge, U. Emanuelson, and K. Holtenius. 2019. Effects of dry period length on metabolic status, fertility, udder health, and colostrum production in 2 cow breeds. J. Dairy Sci 102:595-606. https://doi.org/10.3168/jds.2018-14873.

Andrée O'Hara, E., A. Omazic, I. Olsson, R. Båge, U. Emanuelson, and K. Holtenius. 2018. Effects of dry period length on milk production and energy balance in two cow breeds. Animal 12:508-514. https://doi.org/10.1017/S1751731117001987.

Annen, E. L., R. J. Collier, M. A. McGuire, J. L. Vicini, J. M. Ballam, and M. J. Lormore. 2004. Effect of modified dry period lengths and bovine somatotropin on yield and composition of milk from dairy cows. J. Dairy Sci. 87:3746-3761. https://doi.org/10.3168/ jds.S0022-0302(04)73513-4.

Berge, A. C., and G. Vertenten. 2014. A field study to determine the prevalence, dairy herd management systems, and fresh cow clinical conditions associated with ketosis in western European dairy herds. J. Dairy Sci. 97:2145-2154. https://doi.org/10.3168/jds .2013-7163.

Capuco, A. V., R. M. Akers, and J. J. Smith. 1997. Mammary growth in Holstein cows during the dry period: Quantification of nucleic acids and histology. J. Dairy Sci. 80:477-487. https://doi.org/10 .3168/jds.S0022-0302(97)75960-5.

Chen, J., A. Kok, G. J. Remmelink, J. J. Gross, R. M. Bruckmaier, B. Kemp, and A. T. M. van Knegsel. 2016. Effects of dry period length and dietary energy source on lactation curve characteristics over 2 subsequent lactations. J. Dairy Sci. 99:9287-9299. https:// doi.org/10.3168/jds.2016-11253.

Chen, J., J. J. Gross, H. A. van Dorland, G. J. Remmelink, R. M. Bruckmaier, B. Kemp, and A. T. M. van Knegsel. 2015a. Effects of dry period length and dietary energy source on metabolic status and hepatic gene expression of dairy cows in early lactation. J. Dairy Sci. 98:1033-1045. https://doi.org/10.3168/jds.2014-8612.

Chen, J., N. M. Soede, H. A. van Dorland, G. J. Remmelink, R. M. Bruckmaier, B. Kemp, and A. T. M. van Knegsel. 2015b. Relationship between metabolism and ovarian activity in dairy cows with different dry period lengths. Theriogenology 84:1387-1396. https:/ /doi.org/10.1016/j.theriogenology.2015.07.025.

Collard, B. L., P. J. Boettcher, J. C. Dekkers, D. Petitclerc, and L. R. Schaeffer. 2000. Relationships between energy balance and health traits of dairy cattle in early lactation. J. Dairy Sci. 83:2683-2690. https://doi.org/10.3168/jds.S0022-0302(00)75162-9.

de Feu, M. A., A. C. O. Evans, P. Lonergan, and S. T. Butler. 2009. The effect of dry period duration and dietary energy density on milk production, bioenergetic status, and postpartum ovarian function in Holstein-Friesian dairy cows. J. Dairy Sci. 92:60116022. https://doi.org/10.3168/jds.2009-2374.

de Vries, M. J., and R. F. Veerkamp. 2000. Energy balance of dairy cattle in relation to milk production variables and fertility. J. Dairy Sci. 83:62-69. https://doi.org/10.3168/jds.S0022-0302(00)74856-9.

Esposito, G., P. C. Irons, E. C. Webb, and A. Chapwanya. 2014. Interactions between negative energy balance, metabolic diseases, uterine health and immune response in transition dairy cows. Anim. Reprod. Sci. 144:60-71. https://doi.org/10.1016/j.anireprosci.2013 .11 .007 .
Ferguson, J. D., D. T. Galligan, and N. Thomsen. 1994. Principal descriptors of body condition in Holstein cows. J. Dairy Sci. 77:26952703. https://doi.org/10.3168/jds.S0022-0302(94)77212-X.

Gümen, A., R. R. Rastani, R. R. Grummer, and M. C. Wiltbank. 2005. Reduced dry periods and varying prepartum diets alter postpartum ovulation and reproductive measures. J. Dairy Sci 88:2401-2411. https://doi.org/10.3168/jds.S0022-0302(05)72918 -0 .

Heeren, J. A. H., W. Steeneveld, and P. B. M. Berentsen. 2014. Economic comparison of a sixty day dry period with no dry period on Dutch dairy farms. Livest. Sci. 168:149-158. https://doi.org/10 .1016/j.livsci.2014.08.004.

Ingvartsen, K. L. 2006. Feeding- and management-related diseases in the transition cow: Physiological adaptations around calving and strategies to reduce feeding-related diseases. Anim. Feed Sci Technol. 126:175-213. https://doi.org/10.1016/j.anifeedsci.2005 .08 .003 .

ISO. 2013. ISO 9622: Milk and liquid milk products. Guidelines for the application of mid-infrared spectrometry. International Organization of Standardization, Geneva, Switzerland.

Klusmeyer, T. H., A. C. Fitzgerald, A. C. Fabellar, J. M. Ballam, R. A. Cady, and J. L. Vicini. 2009. Effect of recombinant bovine somatotropin and a shortened or no dry period on the performance of lactating dairy cows. J. Dairy Sci. 92:5503-5511. https://doi .org/10.3168/jds.2009-2390.

KNMvD 2013. Directive of the use of antimicrobials for dry-cow therapy in dairy cows (in Dutch; Richtlijn Antimicrobiële middelen bij het droogzetten van melkkoeien). https://www.knmvd .nl/app/uploads / 2018/07/RICHTLIJN-DROOGZETTEN -MELKKOEIEN.pdf.

Kok, A., J. Chen, B. Kemp, and A. T. M. Van Knegsel. 2019. Review: Dry period length in dairy cows and consequences for metabolism and welfare and customised management strategies. Animal 13(S1):s42-s51. https://doi.org/10.1017/S1751731119001174.

Kok, A., A. T. M. van Knegsel, C. E. van Middelaar, B. Engel, H. Hogeveen, B. Kemp, and I. J. M. de Boer. 2017a. Effect of dry period length on milk yield over multiple lactations. J. Dairy Sci. 100:739-749. https://doi.org/10.3168/jds.2016-10963.

Kok, A., C. E. van Middelaar, B. Engel, A. T. M. van Knegsel, H. Hogeveen, B. Kemp, and I. J. M. de Boer. 2016. Effective lactation yield: A measure to compare milk yield between cows with different dry period lengths. J. Dairy Sci. 99:2956-2966. https:// doi.org/10.3168/jds.2015-10559.

Kok, A., C. E. Van Middelaar, P. F. Mostert, A. T. M. Van Knegsel, B. Kemp, I. J. M. De Boer, and H. Hogeveen. 2017b. Effects of dry period length on production, cash flows and greenhouse gas emissions of the dairy herd: A dynamic stochastic simulation model. PLoS One 12:e0187101. https://doi.org/10.1371/journal pone. 0187101.

Köpf, M., K. Gellrich, H. Küchenhoff, H. H. D. Meyer, and H. Kliem. 2014. Effects of continuous milking during a field trial on productivity, milk protein yield and health in dairy cows. Animal 8:1130-1138. https://doi.org/10.1017/S1751731114001062.

Kuhn, M. T., J. L. Hutchison, and H. D. Norman. 2005. Minimum days dry to maximize milk yield in subsequent lactation. Anim. Res. 54:351-367. https://doi.org/10.1051/animres:2005031.

Littell, R. C., G. A. Milliken, W. W. Stroup, and R. D. Wolfinger. 1996. SAS System for Mixed Models. SAS Institute Inc., Cary, NC

Lucy, M. C. 2001. Reproductive loss in high-producing dairy cattle: Where will it end? J. Dairy Sci. 84:1277-1293. https://doi.org/10 .3168/jds.S0022-0302(01)70158-0.

Rastani, R. R., R. R. Grummer, S. J. Bertics, A. Gümen, M. C. Wiltbank, D. G. Mashek, and M. C. Schwab. 2005. Reducing dry period length to simplify feeding transition cows: Milk production, energy balance, and metabolic profiles. J. Dairy Sci. 88:1004-1014. https://doi.org/10.3168/jds.S0022-0302(05)72768-5.

Scherpenzeel, C. G. M., I. E. M. den Uijl, G. van Schaik, R. G. M. Olde Riekerink, J. M. Keurentjes, and T. J. G. M. Lam. 2014 Evaluation of the use of dry cow antibiotics in low somatic cell 
count cows. J. Dairy Sci. 97:3606-3614. https://doi.org/10.3168/ jds.2013-7655.

Scherpenzeel, C. G. M., I. E. M. den Uijl, G. van Schaik, R. G. M. O. Riekerink, H. Hogeveen, and T. J. G. M. Lam. 2016. Effect of different scenarios for selective dry-cow therapy on udder health, antimicrobial usage, and economics. J. Dairy Sci. 99:3753-3764. https://doi.org/10.3168/jds.2015-9963.

Schlamberger, G., S. Wiedemann, E. Viturro, H. H. D. Meyer, and M. Kaske. 2010. Effects of continuous milking during the dry period or once daily milking in the first 4 weeks of lactation on metabolism and productivity of dairy cows. J. Dairy Sci. 93:2471-2485. https://doi.org/10.3168/jds.2009-2823.

Steeneveld, W., Y. H. Schukken, A. T. M. van Knegsel, and H. Hogeveen. 2013. Effect of different dry period lengths on milk production and somatic cell count in subsequent lactations in commercial Dutch dairy herds. J. Dairy Sci. 96:2988-3001. https://doi.org/10 $.3168 /$ jds.2012-6297.

van Hoeij, R. J., J. Dijkstra, R. M. Bruckmaier, J. J. Gross, T. J. G. M. Lam, G. J. Remmelink, B. Kemp, and A. T. M. van Knegsel. 2017. Consequences of dietary energy source and energy level on energy balance, lactogenic hormones, and lactation curve characteristics of cows after a short or omitted dry period. J. Dairy Sci. 100:8544-8564. https://doi.org/10.3168/jds.2017-12855.

van Hoeij, R. J., T. J. G. M. Lam, R. M. Bruckmaier, J. Dijkstra, G. J. Remmelink, B. Kemp, and A. T. M. van Knegsel. 2018. Udder health of dairy cows fed different dietary energy levels after a short or no dry period without use of dry cow antibiotics. J. Dairy Sci. 101:4570-4585. https://doi.org/10.3168/jds.2017-13448. van Hoeij, R. J., T. J. G. M. Lam, D. B. de Koning, W. Steeneveld, B. Kemp, and A. T. M. van Knegsel. 2016. Cow characteristics and their association with udder health after different dry period lengths. J. Dairy Sci. 99:8330-8340. https://doi.org/10.3168/jds .2016-10901.

Van Knegsel, A. T. M., G. J. Remmelink, S. Jorjong, V. Fievez, and B. Kemp. 2014. Effect of dry period length and dietary energy source on energy balance, milk yield, and milk composition of dairy cows. J. Dairy Sci. 97:1499-1512. https://doi.org/10.3168/jds.2013-7391.

Van Knegsel, A. T. M., S. G. A. Van der Drift, J. Cermáková, and B. Kemp. 2013. Effects of shortening the dry period of dairy cows on milk production, energy balance, health, and fertility: A systematic review. Vet. J. 198:707-713. https://doi.org/10.1016/j.tvjl 2013.10.005.

Vanhoudt, A., K. van Hees-Huijps, A. T. M. van Knegsel, O. C. Sampimon, J. C. M. Vernooij, M. Nielen, and T. van Werven. 2018. Effects of reduced intramammary antimicrobial use during the dry period on udder health in Dutch dairy herds. J. Dairy Sci. 101:3248-3260. https://doi.org/10.3168/jds.2017-13555.

\section{ORCIDS}

A. Kok (ㄴ) https://orcid.org/0000-0002-6024-5339

R. J. van Hoeij @ https://orcid.org/0000-0002-9131-8297

B. Kemp ㄷ https://orcid.org/0000-0002-9765-9105

A. T. M. van Knegsel ๑ https://orcid.org/0000-0003-1959-3363

\section{APPENDIX}

Table A1. Treatment events ${ }^{1}$ of cows in the first 14 wk after calving for cows in different dry period strategies ${ }^{2}$

\begin{tabular}{|c|c|c|c|c|c|c|c|c|}
\hline Item & \multicolumn{7}{|c|}{ Dry period strategy } & Total \\
\hline Ketosis & 0 & 0 & 0 & 0 & 0 & 0 & 0 & 0 \\
\hline Milk fever & 0 & 0 & 0 & 8 & 2 & 2 & 0 & 12 \\
\hline Mastitis & 1 & 0 & 1 & 7 & 2 & 2 & 1 & 14 \\
\hline Vaginal discharge & 0 & 6 & 5 & 8 & 8 & 4 & 3 & 34 \\
\hline Endometritis & 0 & 2 & 6 & 8 & 4 & 1 & 3 & 24 \\
\hline Cystic ovaries & 0 & 1 & 2 & 4 & 2 & 2 & 0 & 11 \\
\hline Other & 0 & 4 & 0 & 0 & 0 & 0 & 1 & 5 \\
\hline Total treatment events & 1 & 18 & 15 & 50 & 25 & 12 & 13 & 134 \\
\hline Disease events (n/cow) & 0.11 & 0.90 & 0.39 & 0.98 & 0.83 & 0.80 & 0.65 & \\
\hline Total number of cows & 9 & 20 & 38 & 51 & 30 & 15 & 20 & \\
\hline
\end{tabular}

${ }^{1}$ Based on treatment records for disease.

${ }^{2} 60 \mathrm{AB}=60$-d dry period with dry-cow antibiotics; $60 \mathrm{TS}=60$-d dry period with teat seal; 30TS $=30$-d dry period with teat seal; 0d $=0$-d dry period. 